GEOPHYSICAL RESEARCH LETTERS, VOL. 20, NO. 24, PAGES 2849-2852, DECEMBER 23, 1993

\title{
ZONAL MEAN WINDS IN THE EQUATORIAL MESOSPHERE AND LOWER THERMOSPHERE OBSERVED BY THE HIGH RESOLUTION DOPPLER IMAGER
}

\author{
R. S. Lieberman, M. D. Burrage, D. A. Gell, P. B. Hays, A. R. Marshall, D. A. Ortland, W. R. Skinner and D. L. Wu
}

Space Physics Research Laboratory, University of Michigan

R. A. Vincent

Department of Physics, University of Adelaide

\author{
S. J. Franke
}

Department of Electrical Engineering, University of Illinois

\begin{abstract}
This paper presents analyses of mesospheric and lower thermospheric zonal mean winds observed by the High Resolution Doppler Imager (HRDI) on the Upper Atmosphere Research Satellite (UARS). Monthly averages of the equatorial zonal mean zonal winds are presented for January 1992 through June 1993. Equatorial zonal winds in the $70-90 \mathrm{~km}$ region are dominated by a semiannual oscillation (SAO), ranging from $30 \mathrm{~m} \mathrm{~s}^{-1}$ (westerly) to $-100 \mathrm{~m} \mathrm{~s}^{-1}$ (easterly). At high latitudes the zonal wind variations are predominantly annual. Above $90 \mathrm{~km}$, the low-latitude flow is easterly at all times, punctuated by a small semiannual variation. This behavior may be related to the deposition of momentum by the diumal tides.
\end{abstract}

\section{Introduction}

The zonal mean circulation in the region of the equatorial middle atmosphere above $35 \mathrm{~km}$ is characterized primarily by a semiannual oscillation (SAO) of the zonal wind and temperature. Previous studies have shown that the equatorial SAO consists of two separate oscillations, centered at the stratopause $(\sim 50 \mathrm{~km})$ and the mesopause $(\sim 85 \mathrm{~km})$, which are approximately $180^{\circ}$ out of phase [Hirota, 1978; Andrews et al., 1987].

The stratopause SAO (SSAO) was discovered in radiosonde and rocketsonde winds by Reed [1965; 1966], and subsequently, documented in the rocket network wind and temperature climatologies of Angel and Korshover [1970], Belmont and Dartt [1973] and Hopkins [1975]. More recently, data from the Nimbus 7 Stratospheric and Mesospheric Sounder (SAMS) and the Limb Infrared Monitor of the Stratosphere (LIMS) have enabled analyses of the SSAO which have contributed substantially to the understanding of the dynamical processes which drive this phenomenon [Hitchman and Leovy, 1986; 1988; Delisi and Dunkerton, 1988]

The mesopause SAO (MSAO) was first depicted by Groves [1972] in a rocket and radar-wind climatology of the meteor region. Using rocketsonde data, Hirota [1978] and Hamilton [1982] confirmed the existence of an MSAO at low latitudes which maximized near $80 \mathrm{~km}$. Peak westerly winds appear at

Copyright 1993 by the American Geophysical Union.

Paper number 93GL03120

0094-8534/93/93GL-03120\$03.00 solstice, with maximum easterlies at equinox. Garcia and Clancy have documented an MSAO in Solar Mesospheric Explorer (SME) temperatures [1990]. More recently, data from ground-based partial-reflection MF and meteor radars at Christmas Island $\left(2^{\circ} \mathrm{N}, 157^{\circ} \mathrm{W}\right)$ and Kauai, Hawaii $\left(22^{\circ} \mathrm{N}\right.$, $160^{\circ} \mathrm{W}$ ) indicate an MSAO near $80-85 \mathrm{~km}$, which exhibits a high degree of interannual variability (D. G. Fritts and J. R. Isler, Mean motions and tidal and two-day structure and variability in the mesosphere and lower thermosphere over Hawaii, submitted to J. Geophy. Res., 1993; S. E. Palo and S. K. Avery, Mean winds and the semiannual oscillation in the mesosphere and lower thermosphere at Christmas Island, submitted to J. Geophy. Res., 1993) [Vincent and Lessicar, 1991; Vincent, 1993a; 1993b].

The High Resolution Doppler Imager (HRDI) winds represent the first direct, long-term observations of the globalscale circulation in the region of the atmosphere above $70 \mathrm{~km}$. In this paper we report the results of an analysis of the zonal mean winds in the mesosphere and lower thermosphere from January 1992 to June 1993.

\section{HRDI Data and Analysis}

HRDI is a triple-etalon Fabry-Perot interferometer/photometer, designed to measure winds in the stratosphere, mesosphere and lower thermosphere. The reader is referred to Hays et al. [1993] and Abreu et al. [1989] for a complete discussion of the instrument design and operation. HRDI measurements are possible only during daylight hours, with the exception of the $95 \mathrm{~km}$ level. The resolution along the orbit track is about $500 \mathrm{~km}$, while the vertical resolution is $2.5 \mathrm{~km}$. The present study is restricted to the daytime winds in the 60 $110 \mathrm{~km}$ range, where the accuracy of the HRDI winds is approximately $\pm 5 \mathrm{~m} \mathrm{~s}^{-1}$ [Burrage et al., 1993]. At these altitudes, daytime winds are usually sampled every other day.

This study utilizes version 5.0 of the HRDI level 2 data, generated at the University of Michigan Space Physics Research Laboratory. Each days' worth of HRDI mesospheric winds are collected in $5^{\circ}$ latitude bins, and then averaged around a latitude circle. Monthly means of these daily zonal averaged winds are formed between January 1992 and March 1992, and from July 1992 to June 1993. In order to ensure a relatively continuous time series, the analyses in this study are confined between $50^{\circ} \mathrm{S}$ and $50^{\circ} \mathrm{N}$. 


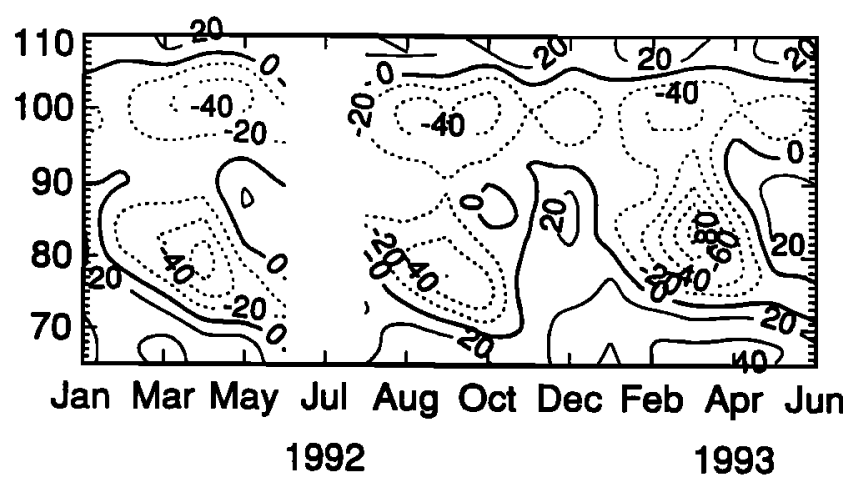

Fig. 1. Altitude-time cross section of HRDI zonal mean zonal wind at the equator. Contour interval is $20 \mathrm{~m} \mathrm{~s}^{-1}$. Dashed contours indicate negative (easterly) values.

\section{HRDI Zonal Mean Winds}

Figure 1 shows the time-height variation of the monthly mean zonally-averaged zonal wind at the equator. Solid lines indicate westerly winds and dotted lines represent easterly winds. Between 70 and $90 \mathrm{~km}$, the pattem is dominated by a variation with a time scale which is approximately semiannual. Following Hitchman and Leovy [1986], we use the term semiannual oscillation (SAO) in reference to the equatorial zonal mean circulation which varies on the approximate 6month time scale previously noted. The SAO is therefore not necessarily synonymous with the second harmonic of the annual cycle.

Maximum MSAO easterlies occur near equinox periods, separated by periods of maximum westerly flow ocurring near the solstices. Peak easterly winds in excess of $-70 \mathrm{~m} \mathrm{~s}^{-1}$ and $-60 \mathrm{~m} \mathrm{~s}^{-1}$ are observed in April and Sept. 1992, respectively. These maxima are situated near $80 \mathrm{~km}$. By contrast, the strongest westerly winds are about one-half the magnitude of the easterly maxima. This asymmetry has been noted in previous studies [Hirota, 1978; Palo and Avery, 1993; Vincent, 1993b]. In 1993, the MSAO maximum easterlies increased dramatically above their 1992 levels, exceeding -100 $\mathrm{m} \mathrm{s}^{-1}$ in April. Westerly winds peaked at about $20 \mathrm{~m} \mathrm{~s}^{-1}$ in 1992 and $30 \mathrm{~m} \mathrm{~s}^{-1}$ in 1993 . Both easterly and westerly wind maxima shifted upward to $85 \mathrm{~km}$ in 1993.

Easterly winds are observed between 90 and $105 \mathrm{~km}$, with a transition to time-mean westerlies occuring at roughly 105 $\mathrm{km}$. A semiannual periodicity appears in the thermospheric easterly flow regime, with peak easterly winds ocurring in conjuction with the easterly phases of the MSAO. These features are also noted in the observations of Palo and Avery [1993] and Vincent [1993a], and may be related to momentum deposition by the diurnal tides as suggested by Lindzen (1981). This premise is further explored in a separate paper.

Figure 2 shows the variation of the zonal mean zonal wind in latitude and time at $80 \mathrm{~km}$. At low latitudes the dominant feature is the semiannual variation, while poleward of $30^{\circ}$ the seasonal variation of the zonal wind is characterized by an annual oscillation. Previous studies have noted the slight asymmetry of the low-latitude stratopause SAO about the equator [Hamilton, 1982], with the maximum amplitude ocurring in the Southern hemisphere. This characteristic is seen in the easterly phase during April 1992 and March 1993; however, in Sept. 1992 peak easterlies are skewed toward the

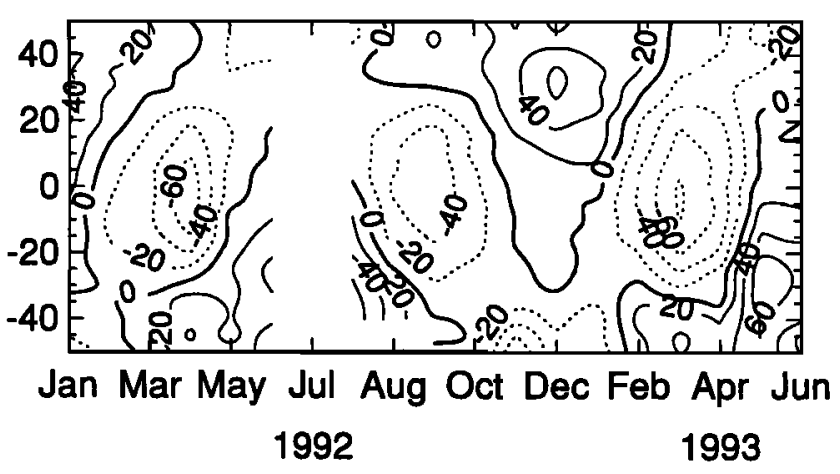

Fig. 2. Latitude-time cross section of HRDI zonal mean zonal wind at $80 \mathrm{~km}$. Contour interval is $20 \mathrm{~m} \mathrm{~s}^{-1}$.

Northern hemisphere. The westerly phase of the low-latitude SAO occurs in concert with midlatitude westerlies in the winter hemisphere and midlatitude easterlies in the summer hemisphere.

Figure 3 shows the monthly averages of the zonal mean meridional wind. As noted by Morton et al. [1993], the zonal averaging of daily HRDI winds sampled at nearly fixed local times enhances the migrating tides along with the mean circulation. In an effort to de-emphasize the tidal component, the time mean has been removed from the analysis in Figure 3. The resulting pattern contains features which are related to the mean meridional flow, and temporal variations in the diurnal tides. At extratropical latitudes an annual cycle appears in the mean meridional wind. The direction of the flow is from the summer hemisphere to the winter hemisphere. Monthly mean northward winds are present between October 1992 and February 1993 over most of the region between $50^{\circ} \mathrm{S}$ and $50^{\circ}$ N. The reverse pattern appears during May-October 1992 and February-June 1993. During these time periods the flow from the summer to the winter hemisphere is interrupted at low latitudes by cells of motion in the opposite sense. These features may be due to incomplete removal of tides, and the meridional circulations accompanying the SAO.

\section{Comparison with Previous Studies and Other Data}

The high degree of interannual variability in the SAO exhibited in Figures 1 and 2 are consistent with the findings of previous and concurent studies of the SAO. Hirota [1978]

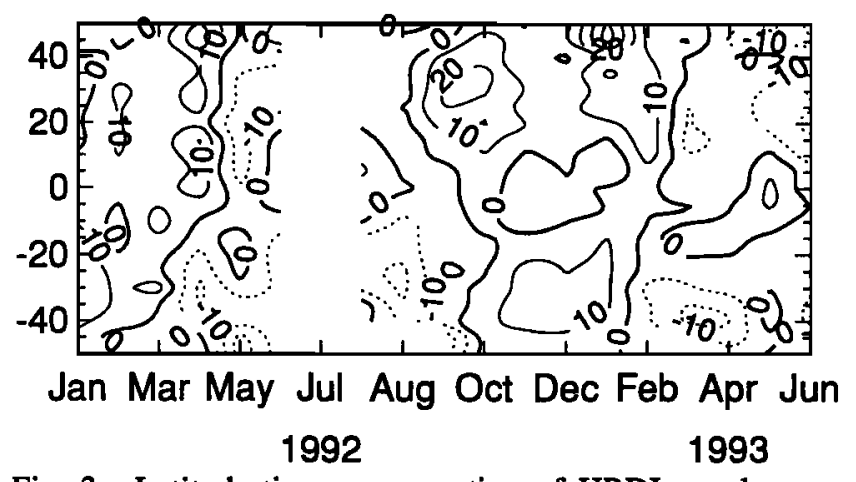

Fig. 3. Latitude-time cross section of HRDI zonal mean meridional wind at $80 \mathrm{~km}$. The time mean has been removed. Contour interval is $10 \mathrm{~m} \mathrm{~s}^{-1}$. 
presented monthly means of mesospheric zonal winds at Ascension Island $\left(8^{\circ} \mathrm{S}, 14^{\circ} \mathrm{W}\right)$ for the period July 1970 January 1972. The level of maximum easterlies is situated near $82 \mathrm{~km}$ in April 1971, shifting to about $78 \mathrm{~km}$ the following year. Palo and Avery reported the shifting positions in the amplitude maxima of the MSAO at Christmas Island $\left(3^{\circ} \mathrm{N}\right.$, $158^{\circ} \mathrm{W}$ ) between 1989 and 1991. Vincent [1993a; 1993b] noted that the easterly phase of the Christmas Island SAO was considerably stronger in the early part of 1990 than in the latter part of the same year. Fritts and Isler similarly commented on cycle-to-cycle and year-to-year variations in the SAO over Kauai, Hawaii $\left(22^{\circ} \mathrm{N}, 160^{\circ} \mathrm{W}\right)$. Garcia and Clancy noted that in the lower mesosphere, the temperature SAO encompassing the December solstice and March equinox was stronger than the cycle covering the remainder of the year (1990).

Figure 4 shows time series of the zonal component of HRDI and contemperaneous radar winds at Urbana $\left(40^{\circ} \mathrm{N}, 88^{\circ}\right.$ $\mathrm{W})$, Adelaide $\left(35^{\circ} \mathrm{S}, 158^{\circ} \mathrm{E}\right)$, and Christmas Island. These data are presented at $80 \mathrm{~km}$ for Adelaide and Christmas Island, and at $81 \mathrm{~km}$ at Urbana. This level was chosen as representative of the mesospheric winds in the regions where HRDI and radar data quality are of high quality. At

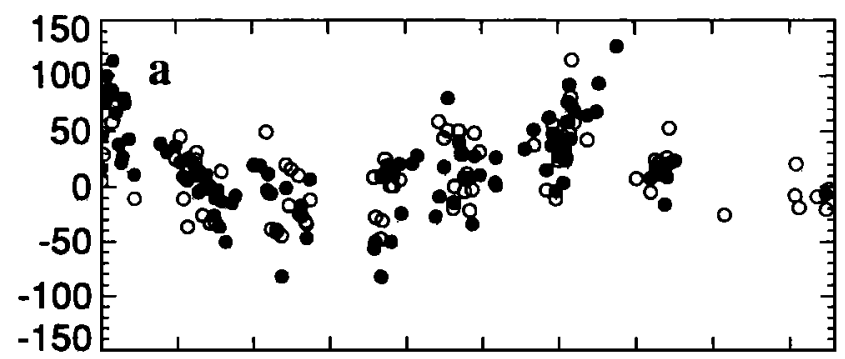

Dec Feb Apr Jun Aug Oct Dec Feb Apr Jun

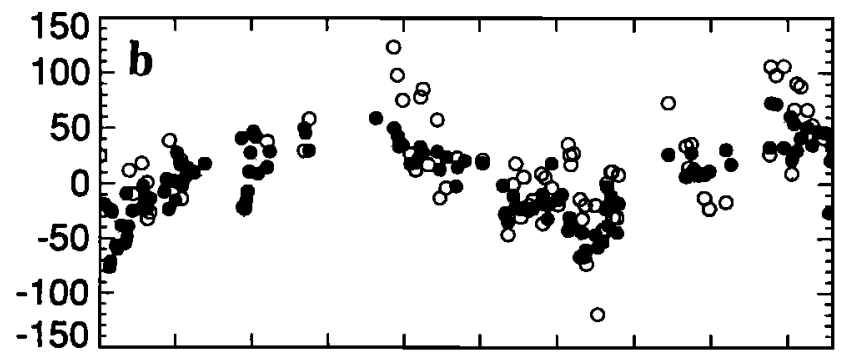

Dec Feb Apr Jun Aug Oct Dec Feb Apr Jun

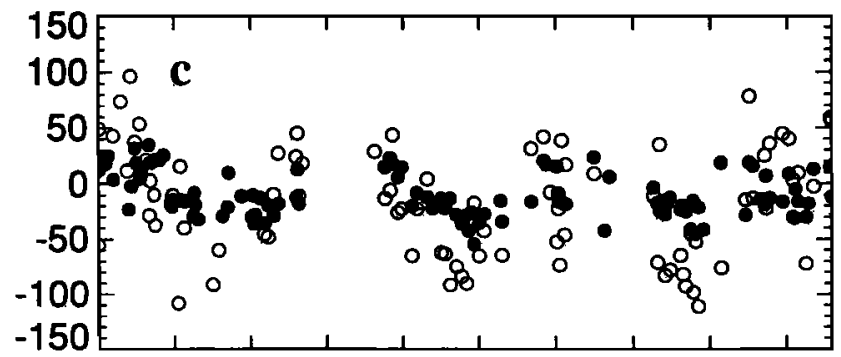

Dec Feb Apr Jun Aug Oct Dec Feb Apr Jun 1992 1993

Fig. 4. (a) Time variation of point HRDI (open circles) and radar (filled circles) winds at Urbana $\left(40^{\circ} \mathrm{N}, 88^{\circ} \mathrm{W}\right)$. (b) As is a, for Adelaide $\left(35^{\circ} \mathrm{S}, 158^{\circ} \mathrm{E}\right)$. (c) As in a, for Christmas Island $\left(2^{\circ} \mathrm{N}, 157^{\circ} \mathrm{W}\right)$. extratropical latitudes, there is general qualitative agreement between HRDI and radar winds. Both datasets reflect the annual cycle of summer easterlies and winter westerlies. At Christmas Island, an MSAO is present in both datasets, with westerlies ocurring at solstices and easterlies prevailing during equinox. Peak HRDI winds exceed the radar winds during both phases, at times by $100 \%$. The reason for these discrepancy is not entirely clear. HRDI measurements represent spatial averages in longitude and along the satellite track. By contrast, the radar measurements shown here are made at a single point, and averaged over 60 minutes. HRDI wind measurements near the equator may be incorporating the signature of tidal winds at neighboring latitudes. Although the dominant mode of the tidal zonal wind possesses a relative minimum at the equator, the gradient of this mode of the tide increases very steeply in the vicinity of this latitude [Chapman and Lindzen, 1970]. Further discussion of the validation of HRDI winds at Christmas Island and other radar sites may be found in Burrage et al. (Validation of wind measurements obtained by the High Resolution Doppler Imager on UARS, submitted to J. Geophy. Res., 1993).

\section{Discussion}

We have presented observations of the global mesospheric and lower thermospheric mean winds seen by HRDI from January 1992 to June 1993. The SAO dominates the lowlatitude zonal wind field between the $70-90 \mathrm{~km}$ levels, with easterly flows descending during equinoxes, replaced by westerly winds during solstice periods. A seasonal asymmetry is observed in the MSAO, characterized by stronger westerlies and easterlies during the December solstice and March equinox, respectively.

The presence of westerly winds at the equator, together with the high temporal variability of the SAO, bears out the hypothesis that this phenomenon is predominantly wavedriven. Dunkerton [1982] has demonstrated that the selective transmission of easterly and westerly gravity waves through the westerly and easterly phases of the SSAO leads to the semiannual periodicity in momentum deposition at mesopause levels. More recently, Delisi and Dunkerton [1988] have explored the seasonal variations of the SSAO. According to their model, stronger planetary wave activity in the northern winter results in a stronger SSAO during the northern hemisphere winter and spring. Garcia and Clancy [1990] have suggested that stronger stratospheric easterlies (westerlies) facilitate more efficient transmission of eastward (westward) propagating gravity waves into the mesosphere. Thus, the asymmetry of the SSAO may account in part for the seasonal asymmetry MSAO.

Kelvin waves of very high phase speeds $\left(110-190 \mathrm{~m} \mathrm{~s}^{-1}\right)$ have been reported in the mesosphere [Hirota, 1978; Salby et al., 1984; Vincent, 1993]. Unlike the Kelvin waves which contribute to the driving of the quasi-biennial oscillation (QBO) and the SSAO, these waves possess vertical wavelengths and intrinsic frequencies which allow them to penetrate into the mesosphere relatively unattenuated. The findings of Dunkerton [1982] suggest that, in addition to gravity waves, momentum deposition by the dissipation of "fast" Kelvin waves may also play a role in the generation of the MSAO westerlies. Vincent [1993] estimated values of $3-10 \mathrm{~m} \mathrm{~s}^{-1}$ day $^{-1}$ for the Kelvin wave. The relative influences of gravity waves and Kelvin 
waves on the momentum budget of the MSAO remains an open question. The mean meridional circulation suggested by Figure 3 implies that away from the equator, Coriolis and advective forces may also contribute to the MSAO dynamics. Efforts are currently under way to estimate the relative contributions of the various forces to the mesospheric zonal momentum budget.

Acknowledgements. We gratefully acknowledge the suggestions of our anonymous reviewers. We thank Deborah Eddy for preparing the manuscript. In addition, RSL wishes to thank Drs. Anne Smith, Rolando Garcia and Susan Avery for helpful discussions. This research was sponsored by NASA Contract NAS 5-27751. The Adelaide and Christmas Island Observations are supported by the Australian Research Council.

\section{References}

Abreu, V. J., A. Bucholtz, P. B. Hays, D. A. Ortland, W. R. Skinner, and J.-H. Yee, Absorption and emission line shapes in the $\mathrm{O}_{2}$ atmospheric bands: Theoretical model and limb viewing simulations, Applied Optics, 28, 2128-2137, 1989.

Andrews, D. G., J. R. Holton and C. B. Leovy, Middle Atmosphere Dynamics, 489 pp., Academic Press, Orlando, FL, 1987.

Angel, J. K. and J. Korshover, Quasi-biennial, annual and semiannual zonal wind and temperature harmonic amplitudes and phases in the stratosphere and low mesosphere of the Northern hemisphere, J. Geophy. Res., 75, 543-550, 1970.

Belmont, A. D. and D. G. Dartt, Semiannual variation in zonal wind from 20 to 65 kilometers at $80^{\circ} \mathrm{N}-10^{\circ} \mathrm{S}, J$. Geophy. Res., 78, 6373-6376, 1973.

Burrage, M. D., W. R. Skinner, A. R. Marshall, P. B. Hays, R. S. Lieberman, S. J. Franke, D. A. Gell, D. A. Ortland, Y. T. Morton, F. J. Schmidlin, R. A. Vincent and D L. $\mathrm{Wu}$, Comparison of HRDI wind measurements with radar and rocket observations, Geophy. Res. Letters, 20, 1259 1262, 1993.

Chapman S. and R. S. Lindzen, Atmospheric Tides, 200 pp., Gordon and Breach, NY, 1970.

Delisi, D. P. and T. J. Dunkerton, Seasonal variation of the semiannual oscillation, J. Atmos. Sci., 45, 2772-2787, 1988.

Dunkerton, T. J., Theory of the mesopause semiannual oscillation, J. Atmos. Sci., 39, 2681-2690, 1982.

Garcia, R. R. and R. T. Clancy, Seasonal variation in equatorial mesospheric temperatures observed by SME, $J$. Atmos. Sci., 47, 1666-1673, 1990.

Groves, G. V., Annual and semi-annual zonal wind components and corresponding temperature and density variations, 60-130 km, Planet. Space Sci., 20, 2099-2112, 1972.

Hamilton, K., Rocketsonde observations of the mesospheric semiannual oscillation at Kwajalein, Atmos.-Ocean, 20, 281-286, 1982.

Hays, P. B., V. J. Abreu, M. E. Dobbs, D. A. Gell, H. J. Grassl, and W. R. Skinner, The High Resolution Doppler
Imager on the Upper Atmosphere Research Satellite, $J$. Geophys. Res., 98, 10,713-10,723, 1993.

Hirota, I., Equatorial waves in the upper stratosphere and mesosphere in relation to the semiannual oscillation of the zonal wind, J. Atmos. Sci., 35, 714-722, 1978.

Hitchman, M. H. and C. B. Leovy, Evolution of the zonal mean state in the equatorial middle atmosphere during October 1978-May 1979, J. Atmos. Sci., 43, 3159-3176, 1986.

Hitchman, M. H. and C. B. Leovy, Estimation of the Kelvin wave contribution to the semiannual oscillation, J. Atmos. Sci., 45, 1462-1475, 1988.

Hopkins, R. H., Evidence for polar-tropical coupling in upper stratospheric zonal wind anomalies, J. Atmos. Sci., 32, 712-719, 1975.

Lindzen, R. S., Turbulence and stress owing to gravity wave and tidal breakdown, J. Geophys. Res., 86, 9707-9714, 1981.

Morton, Y. T., R. S. Lieberman, P. B. Hays, D. A. Ortland, A. R. Marshall, D. Wu, W. R. Skinner, M. D. Burrage, D. A. Gell and J.- H. Yee, Global mesospheric tidal winds observed by the High Resolution Doppler Interferometer on board the Upper Atmosphere Research Satellite, Geophy. Res. Letts., 20, 1263 -1266, 1993.

Reed, R. J., The quasi-biennial oscillation of the atmosphere between 30 and $50 \mathrm{~km}$ over Ascension Island, J. Atmos. Sci., 22, 331-333, 1965.

Reed, R. J., Zonal wind behavior in the equatorial stratosphere and lower meosphere, J. Geophy. Res., 71, 4223-4233, 1966.

Salby, M. L., D. L. Hartmann, P. L. Bailey and J. C. Gille, Evidence for equatorial Kelvin modes in Nimbus 7 LIMS, J. Atmos. Sci., 40, 220-235, 1984.

Vincent, R. A. and D. Lessicar, Dynamics of the equatorial mesosphere: First results with a new generation partial reflection radar, Geophy. Res. Letters, 18, 825-828, 1991.

Vincent, R. A., Low frequency dynamics of the equatorial mesosphere, in Coupling processes in the lower and middle atmospheres, edited by E. V. Thrane et al., pp. 125-136, Kluwer, Dordrecht, 1993a.

Vincent, R. A., Long-period motions in the equatorial middle atmosphere, J. Atmos. Terr. Phys., 55, 1067-1080, $1993 b$.

M. D. Burrage, D. A. Gell, P. B. Hays, R. S. Lieberman, A. R. Marshall, D. A. Ortland, W. R. Skinner and D. L. Wu, Space Physics Research Laboratory, University of Michigan, Ann Arbor, MI 48109-2143.

S. J. Franke, Department of Electrical Engineering, University of Illinois, 1406 W. Green Street, Urbana, IL 61801.

R. A. Vincent, Department of Physics, University of Adelaide, GPO Box 498, Adelaide 5001, Australia.

(Received October 4, 1993; accepted October 27, 1993) 